\author{
Article \\ Doi 10.5943/mycosphere/8/10/14 \\ Copyright $\odot$ Guizhou Academy of Agricultural Sciences
}

\title{
Four new species of Trichoderma with hyaline ascospores from southwest China
}

\author{
Zhang $\mathrm{YB}^{1,2}$, Zhuang $\mathrm{WY}^{1 *}$ \\ ${ }^{1}$ State Key Laboratory of Mycology, Institute of Microbiology, Chinese Academy of Sciences, Beijing 100101, China \\ ${ }^{2}$ University of Chinese Academy of Sciences, Beijing 100049, China
}

Zhang YB, Zhuang WY 2017 - Four new species of Trichoderma with hyaline ascospores from southwest China. Mycosphere 8(10), 1914-1929 Doi 10.5943/mycosphere/8/10/14

\begin{abstract}
Collections of Trichoderma were made from southwest China and examined. Four new species producing hyaline ascospores, $T$. fructicola, $T$. medogense, $T$. palidulum and $T$. virgineum, were found, and are described and illustrated. Their phylogenetic positions were allocated based on sequence analyses of the combined RNA polymerase II subunit $b$ and translation elongation factor 1 alpha genes. Trichoderma fructicola, appearing as a lone lineage among hyaline-ascospored groups, is diagnostic by cortical tissues of textura epidermoidea, remarkable colour change of peridium in $\mathrm{KOH}$, and verticillium- to trichoderma-like conidiophores. As a sister of T. voglmayrii, T. medogenseis similar to T. voglmayrii in having yellow-brown to purplish red stromata and trichoderma-like conidiophores, but differs in apapillate ostioles, subcortical tissues of textura intricata, narrow phialides, andsmaller conidia. Trichoderma palidulumis located in the Viride clade andis distinct from its alliesin stroma and colony morphology. Trichoderma virgineum is closely associated with $T$. henanense and $T$. odoratum. The three species are similar in having yellowish stromata, monomorphic ascospores, white colonies produced on three standard media, simple-branched conidiophores, and hyaline conidia for which anew clade is proposed. Morphological distinctions and sequence divergences between the new species and their close relatives are discussed.
\end{abstract}

Key words - 4 new species - Hypocreales - Morphology - Sequence analysis - Taxonomy

\section{Introduction}

Trichoderma Pers. is a hyperdiverse genus with an extraordinarily high number of species. It is cosmopolitan on various substrates in a wide range of geographic distributions (Chaverri \& Samuels 2003, Kredics et al. 2010). Some species of the genus are found to be beneficial and applied to agriculture, industry and environmental protection (Harman 2006, Bischof et al. 2016, Saravanakumar \& Kathiresan 2014, Adnan et al. 2017). Recognizing its biodiversity and exploring continuously new recourses of the group attract the attention of many researchers from diverse regions of the world.

Trichoderma species are characterized by perithecia immersed in fleshy stromata of different colours, cylindrical asci with hyaline or green ascospores which disarticulate at the septum, conidiophores forming several types of branch patterns, and hyaline or green conidia (Jaklitsch et al. 2006, Qin \& Zhuang 2016c). Bissett et al. (2015) listed 254 species of the genus with either cultures or DNA sequence data available. More recently, about 40 taxa have been added to the 
genus (Qin \& Zhuang 2016a, 2016b, 2016c, 2017, Chen \& Zhuang 2017a,b,c, Sun et al. 2016). Classical approaches alone are difficult to make taxonomic opinions of Trichoderma species. In recent years, combined analyses of morphology and DNA sequence data have accelerated taxonomic studies of the genus. As a result, ascospore colour has been shown to provide useful phylogenetic information (Chaverri \& Samuels 2003, Jaklitsch 2009, 2011). Almost all greenascospored species clustered together and divided into five clades, Ceramicum, Chlorosporum, Harzianum, Spinulosum and Strictipile. The hyaline-ascospored groups seem to be paraphyletic (Jaklitsch \& Voglmayr 2015), which are mainly in ten clades or groups, i.e. Asterineum, Brevicompactum, Deliquescens, Hypocreanum, Longibrachiatum, Polysporum, Psychrophilum, Semiorbis, Stromaticum and Viride. The Viride clade containing about 70 species is so far the largest clade, while the small clades comprised only two or three taxa, such as Asterineum and Ceramicum (Chaverri \& Samuels 2003, Qin \& Zhuang 2016c). Although Trichoderma is among the genera thoroughly investigated, there are still a number of species with their phylogenetic positions not fully understood (Druzhinina \& Kubicek 2005).

During the investigations of Trichoderma species in southwest China, four new hyalineascospored species were discovered, which are named as T.fructicola, T. medogense, T. palidulum and $T$. virgineum. Their sexual and asexual morphsare described and illustrated, and their phylogenetic positions are determined based on sequence analyses of the combined RNA polymerase II subunit B (RPB2) and translation elongation factor 1 alpha (TEF1) genes.

\section{Materials \&methods}

Specimens investigated were collected from Tibet Autonomous Region and Yunnan Province, and deposited in the Herbarium Mycologicum Academiae Sinicae (HMAS). Strains were isolated from ascospores (Jaklitsch 2009), and deposited in the State Key Laboratory of Mycology, Institute of Microbiology, Chinese Academy of Sciences.

The isolates were cultured at $25^{\circ} \mathrm{C}$ with a $12 \mathrm{~h}$ light/dark cycle on Cornmeal Dextrose agar [CMD: 40g cornmeal, $2 \%(W / V)$ dextrose, $2 \%(W / V)$ agar], potato dextrose agar[PDA: 200g potato, $2 \%(W / V)$ dextrose, $2 \%(W / V)$ agar], and synthetic low nutrient agar (SNA, Nirenberg 1976). Radial growth rates of colonies were measured. Morphology of asexual and sexual states was observed following Chaverri \& Samuels (2003). Photographs were taken with a Canon G15 digital camera (Tokyo, Japan) and a Leica DFC450 digital camera (Wetzlar, Germany) attached to a Leica M125 stereomicroscope (Milton Keynes, UK) for gross morphology, and a Zeiss AxioCam MRc 5 digital camera (Jena, Germany) attached to a Zeiss Imager A2 microscope (Göttingen, Germany) for anatomical structures.

Mycelium was harvested to extract genomic DNA following the methods of Wang \& Zhuang (2004). Fragments of RPB2 and TEF1were amplified with the primer pairs and method reported by Jaklitsch (2009) and sequenced at the Beijing Tianyihuiyuan Bioscience and Technology, China.

The sequences used in phylogenetic analysis were listed in Table 1, including sixty Trichoderma species representing fifteen named clades and several independent terminal branches. They were assembled, manually adjusted and aligned using the DNAStar Seqman program 7.1.0 (DNASTAR. Inc., Madison) and ClustalX 1.83 (Thompson et al. 1997).

Maximum parsimony (MP) and Bayesian inference (BI) analyses were conducted to allocate the phylogenetic positions of the new species. MP analysis was carried out using PAUP v. 4.0b10 (Swofford 2002) with following settings: all characters were equally weighted, gaps were treated as missing data, starting trees were obtained by random taxon addition with 1000 replicates, branchswapping algorithm was tree-bisection-reconnection (TBR), steepest descent option and MulTrees option were not in effect. BI analysis was implemented with MrBayes v. 3.1.2 (Ronquist \& Huelsenbeck 2003), and the best-fit model GTR+I+G was selected by MrModelTest v. 2.3 (Nylander 2004) using Akaike information criterion (AIC); Metropoles-coupled Markov chain Monte Carlo (MCMCMC) searches were run for 1000000 generations sampling every 100 generations; the first 2500 trees were discarded as the burn-in phase. The statistic supports were 
evaluated by maximum parsimony bootstrap proportion (MPBP) and Bayesian inference posterior probability (BIPP). Trees were viewed in FigTree v. 1.4.3 (Rambaut 2016).

Table 1 Trichoderma species used in phylogenetic analyses.

\begin{tabular}{|c|c|c|c|}
\hline \multirow[t]{2}{*}{ Species } & \multirow[t]{2}{*}{ Strain } & \multicolumn{2}{|c|}{ GenBank accessionnumbers } \\
\hline & & RPB2 & TEF1 \\
\hline Trichoderma alcalifuscescens (Overton) & TFC 00-36 & - & FJ860610 \\
\hline Jaklitsch \& Voglmayr & TFC 181548 & DQ834462 & - \\
\hline T. asterineum W.T. Qin \& W.Y. Zhuang & HMAS 271353 & KT224469 & KT224465 \\
\hline T. barbatum Samuels & GJS 04-308 & HQ342286 & HQ342223 \\
\hline T. bavaricum Jaklitsch & CPK 2021 & FJ860526 & FJ860620 \\
\hline $\begin{array}{l}\text { T. brevicompactum G.F. Kraus, C.P. Kubicek } \\
\& \text { W. Gams }\end{array}$ & GJS 04-381 & EU338317 & EU338299 \\
\hline $\begin{array}{l}\text { T. britdaniae (Jaklitsch \& Voglmayr) Jaklitsch } \\
\text { \& Voglmayr }\end{array}$ & WU 31610 & JQ685880 & JQ685866 \\
\hline T. caribbaeum Samuels \& Schroers & GJS 97-3 & KJ665246 & KJ665443 \\
\hline T. christiani Jaklitsch \& Voglmayr & $\mathrm{S} 442$ & KJ665244 & KJ665439 \\
\hline T. citrinoviride Bissett & S20 & KJ665250 & KJ665449 \\
\hline T. confluens W.T. Qin \& W.Y. Zhuang & HMAS 244993 & KT001964 & KT001959 \\
\hline T. crystalligenum Jaklitsch & CBS 118980 & DQ345347 & DQ345342 \\
\hline T. cuneisporum P. Chaverri \& Samuels & GJS 91-93 & AF545512 & AF534600 \\
\hline T. danicum Jaklitsch & CBS 121273 & FJ860534 & FJ860634 \\
\hline \multirow[t]{2}{*}{ T. deliquescens (Sopp) Jaklitsch } & CBS 121132 & - & FJ860644 \\
\hline & CBS 121131 & FJ179609 & - \\
\hline T. estonicum P. Chaverri \& Samuels & GJS 96-129 & AF545514 & AF534604 \\
\hline \multicolumn{4}{|l|}{ Voglmayr } \\
\hline T. fomiticola Jaklitsch & CBS 121136 & FJ860538 & FJ860639 \\
\hline T. fructicola Y.B. Zhang \& W.Y. Zhuang & HMAS 275663 & MG383484* & MG383490 \\
\hline T. grande W.T. Qin \& W.Y. Zhuang & HMAS 248749 & KX066266 & KX066254. \\
\hline T. istrianum Jaklitsch \& Voglmayr & S123 & KJ665280 & KJ665521 \\
\hline T. hamatum (Bonord.) Bainier & Нуро 647 & KJ665274 & KJ665513 \\
\hline T. henanense W.T. Qin \& W.Y. Zhuang & HMAS 252889 & KT224467 & KT224464 \\
\hline T. hubeiense W.T. Qin \& W.Y. Zhuang & HMAS 271352 & KT001963 & KT001958 \\
\hline T. koningii Oudem. & S227 & JN715609 & KC285596 \\
\hline T. leguminosarum Jaklitsch \& Voglmayr & S391 & KJ665287 & KJ665548 \\
\hline T. luteocrystallinum Jaklitsch & CBS 123828 & FJ860544 & FJ860646 \\
\hline \multirow[t]{2}{*}{ T. medogense Y.B. Zhang \&W.Y. Zhuang } & HMAS 254526 & MG383486 & MG383491 \\
\hline & HMAS 275662 & MG383485 & MG383492 \\
\hline T. melanomagnum P. Chaverri \& Samuels & GJS 99-153 & AY391926 & AY391985 \\
\hline \multirow[t]{2}{*}{ T. moravicum Jaklitsch } & CPK 2489 & FJ860549 & - \\
\hline & CBS 120539 & - & FJ860651 \\
\hline T. neorufum (Samuels, Dodd \&Lieckf.) & CBS 119498 & FJ860550 & FJ860653 \\
\hline \multicolumn{4}{|l|}{ Jaklitsch \& Voglmayr } \\
\hline T. neorufoides Jaklitsch & CPK 1904 & FJ860554 & FJ860658 \\
\hline T. odoratum W.T. Qin \& W.Y. Zhuang & HMAS 271354 & KT224468 & KT224463 \\
\hline \multirow[t]{2}{*}{ T. palidulum Y.B. Zhang \& W.Y. Zhuang } & HMAS 275665 & MG383487 & MG383493 \\
\hline & HMAS 254527 & MG383488 & MG383494 \\
\hline $\begin{array}{l}\text { T. paraviridescens Jaklitsch, Samuels \& } \\
\text { Voglmayr }\end{array}$ & $\mathrm{S} 122$ & KC285764 & KC285671 \\
\hline T. parestonicum Jaklitsch & CBS 120636 & FJ860565 & FJ860667 \\
\hline
\end{tabular}


Table 1 Continued.

\begin{tabular}{|c|c|c|c|}
\hline \multirow[t]{2}{*}{ Species } & \multirow[t]{2}{*}{ Strain } & \multicolumn{2}{|c|}{ GenBank accessionnumbers } \\
\hline & & RPB2 & TEF1 \\
\hline $\begin{array}{l}\text { T. parareesei Atan., Jaklitsch, Komoń-Zel., } \\
\text { C.P. Kubicek \& Druzhin. }\end{array}$ & TUB F-1066 & HM182963 & GQ354353 \\
\hline T. petersenii Samuels, Dodd \& Schroers & CBS 119507 & FJ860568 & FJ860670 \\
\hline T. phellinicola Jaklitsch & CBS 119283 & FJ860569 & FJ860672 \\
\hline T. polysporum (Link) Rifai & CPK 3131 & FJ860558 & FJ860661 \\
\hline T. psychrophilum Jaklitsch & CPK 2435 & FJ860576 & FJ860682 \\
\hline $\begin{array}{l}\text { T. rhododendri (Jaklitsch) Jaklitsch \& } \\
\text { Voglmayr }\end{array}$ & CBS 119288 & FJ860578 & FJ860685 \\
\hline T. rossicumBissett, C.P. Kubicek \& Szakács & S334 & KJ665335 & KJ665700 \\
\hline $\begin{array}{l}\text { T. sambuci (Jaklitsch \& Voglmayr) Jaklitsch \& } \\
\text { Voglmayr }\end{array}$ & WU 29467 & FJ860585 & FJ860693 \\
\hline T. saturnisporopsis Samuels \& Jaklitsch & S19 & JQ685885 & JQ685869 \\
\hline T. semiorbis (Berk.) Jaklitsch \& Voglmayr & $\begin{array}{c}\text { DAOM } \\
167636\end{array}$ & AF545522 & AF545568 \\
\hline T. sinokoningii W.T. Qin \& W.Y. Zhuang & HMAS 271397 & KU529141 & KU529130 \\
\hline T. sinuosum P. Chaverri \& Samuels & CPK 1595 & FJ179619 & FJ860697 \\
\hline T. spinulosum Fuckel & CBS 121272 & FJ860590 & FJ860700 \\
\hline T. strictipile Bissett & CPK 1601 & FJ860594 & FJ860704 \\
\hline T. stromaticum Samuels \& Pardo-Schulth. & GJS 97-183 & HQ342245 & AY937418 \\
\hline T. subalpinum Jaklitsch & CPK 3126 & FJ860596 & FJ860706 \\
\hline T. subeffusum Jaklitsch & CBS 120929 & FJ860597 & FJ860707 \\
\hline T. thelephoricola P. Chaverri \& Samuels & CBS 120925 & FJ860600 & FJ860711 \\
\hline T. tomentosum Bissett & S33 & KF134793 & KF134801 \\
\hline T. tremelloides Jaklitsch & CBS 120634 & FJ860602 & FJ860713 \\
\hline T. virgineum Y.B. Zhang \& W.Y. Zhuang & HMAS 275664 & MG383489 & MG383495 \\
\hline T. viride Pers. & CBS 119325 & EU711362 & DQ672615 \\
\hline T. voglmayrii Jaklitsch & CBS 117710 & DQ086151 & DQ086147 \\
\hline T. yui Z.X. Zhu \& W.Y. Zhuang & HMAS 266633 & KJ634725 & KJ634758 \\
\hline T. yunnanense Z.F. Yu \& K.Q. Zhang & CBS 121219 & GU198274 & GU198243 \\
\hline Nectria berolinensis (Sacc.) Cooke & CBS 127382 & HM534883 & HM534872 \\
\hline N. eustromatica Jaklitsch \& Voglmayr & CBS 121896 & HM534886 & HM534875 \\
\hline
\end{tabular}

*Numbers in boldface indicate the newly submitted sequences.

\section{Results}

\section{Phylogenetic analyses}

The partition homogeneity test $(\mathrm{P}=0.01)$ indicated that the individual partitions were not highly incongruent (Cunningham 1997), and thus, RPB2 and TEF1 were combined for sequence analyses. The combined dataset contained 64sequences and 2437 characters (1082 characters forRPB2, 1355 characters for TEF1), of which 62sequences represented 60Trichoderma species. In the MP analysis, 1248 characters were constant, 171 variable characters were parsimonyuninformative, and 1018 were parsimony-informative. The MP analysis resulted in two most parsimonious trees, and one of them was depicted in Fig.1 (Tree length $=8970$, Consistency index $=$ 0.2591 , Homoplasy index $=0.7409$, Rescaled consistency $=0.1377$, Retention index $=0.5314$ ). The $\mathrm{BI}$ tree is similar to the MP tree in topology. The phylogenetic tree and DNA sequence alignments are deposited in TreeBASE(no. S21884). 
Sixty Trichoderma species representing 15named clades, a newly proposed clade, and some independent terminal branches were analyzed. All the investigated species clustered together with

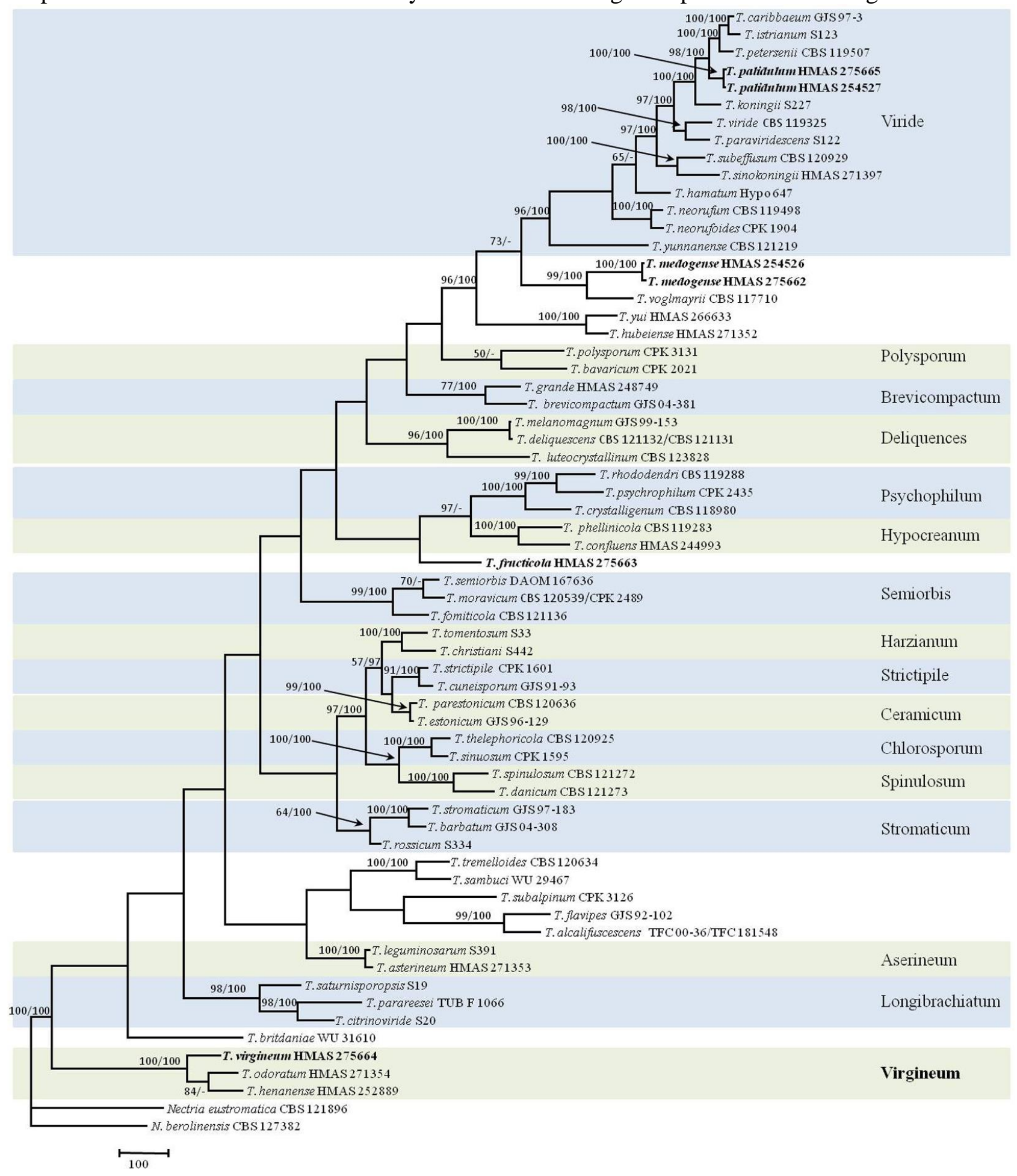

Figure 1 - Maximum parsimony tree of selected Trichoderma species inferred from the combined partial sequences of RPB2 and TEF1showing the phylogenetic positions of the new species. MPBP above 50\% (left) and BIPP above 90\% (right) are indicated at the nodes. New species and clade proposed are in boldface (TreeBASE no. S21884).

high statistical support (Fig.1, MPBP/BIPP $=100 \% / 100 \%$ ). The analyses revealed the phylogenetic positions of the new species. Trichoderma fructicola formed a separate terminal branch, which wasneither close to the Hypocreanum clade nor to the Semiorbis clade. Trichoderma medogense became a sister of T. voglomayrii (Fig.1, MPBP/BIPP $=99 \% / 100 \%$ ) which formerly appeared as an 
independent terminal branch (Jaklitsch 2011, Jaklitsch \& Voglmayr 2015). The collections of $T$. palidulum were located in the Viride clade and associated with T. caribbaeum, T. istrianumand T. petersenii $(\mathrm{MPBP} / \mathrm{BIPP}=98 \% / 100 \%)$. Trichoderma virgineum turned out to be most closely related to $T$. odoratum and T. henanense receiving very high statistic values (MPBP/ BIPP $=100 \% / 100 \%)$.

\section{Taxonomy}

Trichodermafructicola Y.B. Zhang \& W.Y. Zhuang, sp. nov.

Fig. 2

Fungal Names: FN570501; Facesoffungi number: FoF 03915

Etymology - The specific epithet refers to the substrate of the fungus.

Stromata solitary, gregarious or aggregated in small numbers, pulvinate or discoidal, outline circular or elongate to irregular, rounded, broadly attached, pale orange-yellow when fresh, apricot yellow when mature, $0.5-2.5 \mathrm{~mm}$ diam., $0.4-0.7 \mathrm{~mm}$ thick $(\mathrm{n}=35)$. Surface nearly smooth, the stroma bases surrounded with whitish hyphae. Ostiolar dots dark brown, distinct, densely distributed. Rehydrated stromata deep chrome to orange brown, darkened in $3 \% \mathrm{KOH}$.

In section, cortical tissue of textura epidermoidea, $(12.5-) 14.5-26(-29) \mu \mathrm{m}$ thick $(\mathrm{n}=30)$, cells hyaline to yellowish, thin-walled, $(5-) 6.5-17.5(-20) \times 3-11.5 \mu \mathrm{m}(\mathrm{n}=30)$, turning orange red in $3 \% \mathrm{KOH}$; subcortical tissue of textura intricata, hyphae hyaline, thin-walled, 2.0-4.5 $\mu \mathrm{m}(\mathrm{n}=$ 32) wide; subperithecial tissues of textura epidermoidea, cells hyaline, thin-walled, 6.5-32 × 4.5$13.5 \mu \mathrm{m}(\mathrm{n}=33)$; tissue at the base of textura epidermoidea mixed with textura intricata, cells hyaline to light yellow, thin-walled, 4.5-28 $\times 2.5-8.5 \mu \mathrm{m}(\mathrm{n}=30)$, hyphae hyaline to light yellow, thin-walled, 3-6.5 $\mu \mathrm{m}(\mathrm{n}=30)$ wide. Perithecia flask-shaped or globose, $228-286 \times 99.5-215.5 \mu \mathrm{m}$ $(\mathrm{n}=30)$; peridium pale yellow, turning orange red in $3 \% \mathrm{KOH}, 5-14.5 \mu \mathrm{m}$ thick at flanks, 9-16 $\mu \mathrm{m}$ thick at the base $(\mathrm{n}=30)$. Ostioles $14-39.5(-53.5) \mu \mathrm{m}$ wide at apex, 50-86(-94.5) $\mu \mathrm{m}$ high $(\mathrm{n}$ $=30)$. Asci cylindrical, 57.5-85 × 3-4.5 $\mu \mathrm{m}$, with a stipe 4.5-10 $\mu \mathrm{m}$ long $(\mathrm{n}=30)$. Ascospores hyaline, verrucose, cells dimorphic, distal cells globose to ellipsoidal, $1.5-3.5 \times 2.5-4 \mu \mathrm{m}$, L/W 11.6(-1.9), proximal cells ellipsoidal to cylindrical, 3-5 × 1.5-2.5 $\mu \mathrm{m}, \mathrm{L} / \mathrm{W}(1.2-) 1.4-2.6(\mathrm{n}=41)$.

Colony on CMD 29-33 mm in radius after $72 \mathrm{~h}$ at $25^{\circ} \mathrm{C}$, mycelium covering the plate after 9 d. Colony circular, margin well defined; aerial hyphae short and sparsely disposed, longer and denser towards the distal margin. Conidiation noted after $3 \mathrm{~d}$ on aerial hyphae. No distinct odor and diffusing pigment observed.

Colony on PDA $27-31 \mathrm{~mm}$ in radius after 72 hat $25{ }^{\circ} \mathrm{C}$, mycelium covering the plate after 9 d. Colony nearly circular, zonate; aerial hyphae cottony. Conidiation noted after $1 \mathrm{~d}$ on aerial hyphae near the plug. No distinct odor and diffusing pigment observed.

Colony on SNA 8-9 mm in radius after $72 \mathrm{~h}$ at $25^{\circ} \mathrm{C}, 25-30 \mathrm{~mm}$ after $13 \mathrm{~d}$. Colony irregular, thin, margin diffuse; aerial hyphae loosely disposed. Conidiation noted after $3 \mathrm{~d}$ on aerial hyphae. Conidiophores verticillium- to trichoderma-like, branches paired, unpaired, or with up to 4 branches in a whorl around the main axis at an acute or right angle, generally re-branching 1 or 2 times. Phialides subulate or ampulliform, solitary or divergent in whorls of 2-6, 5.5-25.5 $\times 2-3.5$ $\mu \mathrm{m}, \mathrm{L} / \mathrm{W} 1.8-8.7$, base 1.5-3.2 $\mu \mathrm{m}(\mathrm{n}=43)$. Conidia pale green, globose, oblong or ellipsoid, 2.5$4.5 \times 2-3 \mu \mathrm{m}, \mathrm{L} / \mathrm{W} 1-2(\mathrm{n}=30)$. No distinct odor and diffusing pigment observed.

Material examined - CHINA, Yunnan, Maguan County, 22 $50.81^{\prime} \mathrm{N}, 104^{\circ} 31.79^{\prime} \mathrm{E}$, alt. 1587 m, on a rotten fruit, 12 August 2016, X.H. Wang, S.H. Li, H.D. Zheng \& S.C. Li YN16-88 (HMAS 275663 holotype); ex-type culture HMAS247235.

Notes - Trichoderma fructicola is diagnostic by the cortical tissues of textura epidermoidea, remarkable colour change of peridium in $\mathrm{KOH}$, hyaline ascospores, verticillium- to trichodermalike conidiophore branching pattern, and occurrence on a rotten fruit. Sequence analyses indicate that the fungus forms a separate phylogenetic lineage. Sequence comparisons (NCBI database: https://www.ncbi.nlm.nih.gov/) reveal that the new species shares 95\% similarity with that of $T$. strictipile (54 bp divergences among $1030 \mathrm{bp}$ in the region ofTEF1); it has 92\% identity to T. taxi but is with $92 \mathrm{bp}$ differences among $1089 \mathrm{bp}$ for the fragment of RPB2. 


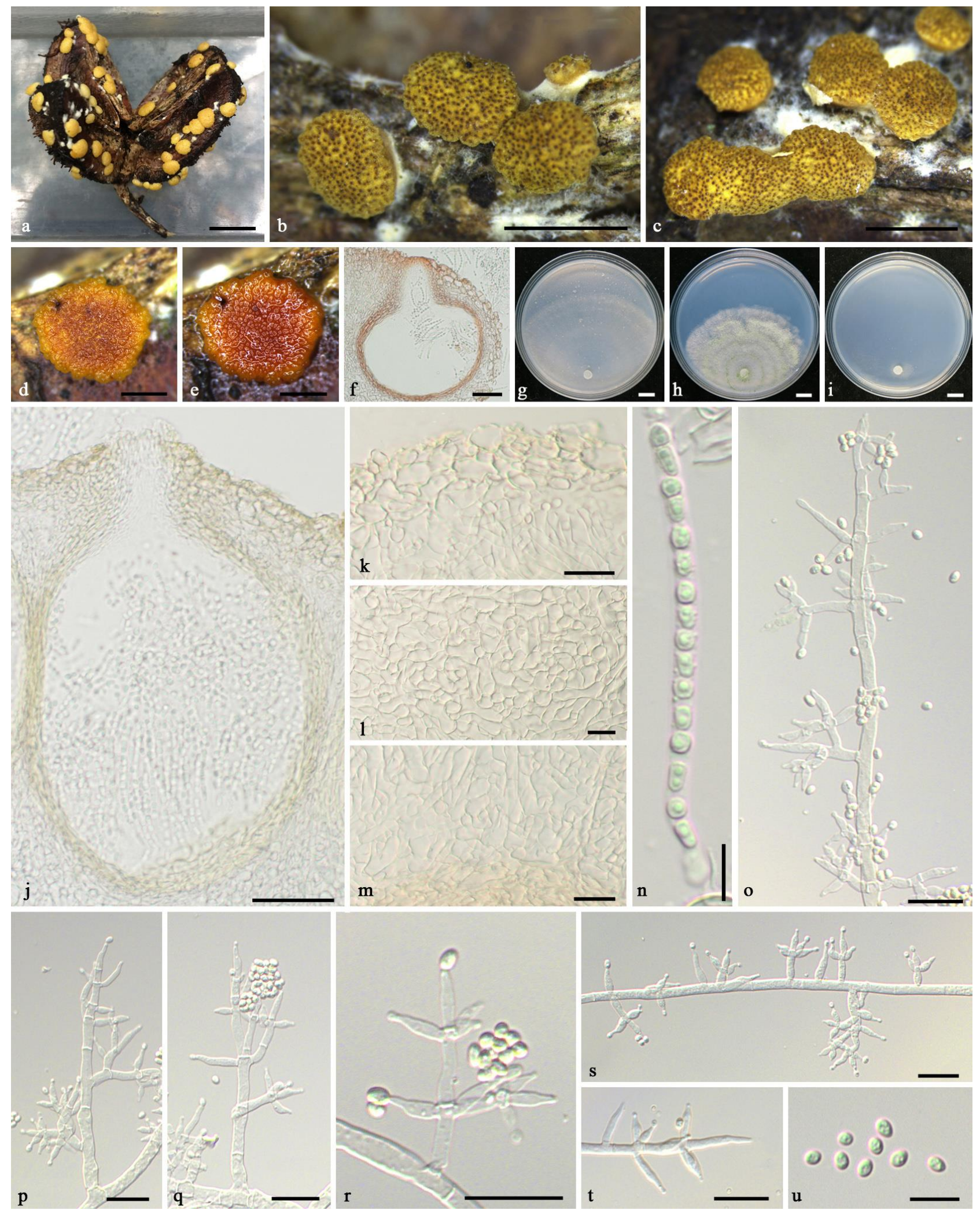

Figure 2 - Trichoderma fructicola (HMAS 275663). a Fresh stromata on natural substrate b, c Dry stromata on natural substrate d Mature stroma after rehydration e Rehydrated mature stroma in 3\% $\mathrm{KOH} \mathrm{f}$ Longitudinal section of a perithecium in $\mathrm{KOH} \mathrm{g}-\mathrm{i}$ Cultures after 7 days at $25^{\circ} \mathrm{C}(\mathrm{g} \mathrm{CMD}, \mathrm{h}$ PDA, i SNA) j Perithecium in section k Cortical and subcortical tissues in section 1 Subperithecial tissue in section $\mathrm{m}$ Stroma base in section $\mathrm{n}$ Ascus o-t Conidiophores and phialides (SNA, 7days) $\mathrm{u}$ Conidia (PDA, 11 days).-Scale bars: $a, g-i=10 \mathrm{~mm}, \mathrm{~b}, \mathrm{c}=2 \mathrm{~mm}, \mathrm{~d}, \mathrm{e}=1 \mathrm{~mm}, \mathrm{f}, \mathrm{j}=500 \mu \mathrm{m}, \mathrm{k}-\mathrm{m}$ $=200 \mu \mathrm{m}, \mathrm{n}, \mathrm{u}=10 \mu \mathrm{m}, \mathrm{o}-\mathrm{t}=20 \mu \mathrm{m}$. 
Trichodermamedogense Y.B. Zhang \& W.Y. Zhuang, sp. nov.

Fungal Names: FN570502; Facesoffungi number: FoF 03916

Etymology - The specific epithet refers to the type locality of the fungus.

Stromata solitary or gregarious, pulvinate, discoidal or turbinate, outline circular or variable, centrally attached, margin usually acute and sometimes slightly upwards, yellowish brown, reddish brown or purple red, $0.5-3 \mathrm{~mm}$ diam., $0.2-0.5 \mathrm{~mm}$ thick $(\mathrm{n}=30)$. Surface smooth. Ostiolar dots inconspicuous. Rehydrated stromata English red, becoming reddish brown in $3 \% \mathrm{KOH}$.

In section, cortical tissue of textura angularis, 8.5-13.5 $\mu \mathrm{m}$ thick $(\mathrm{n}=33)$, cells orange, thick-walled, $2.5-8.4 \times 1.9-5.8 \mu \mathrm{m}(\mathrm{n}=55)$, no color change in $3 \% \mathrm{KOH}$; subcortical tissue of textura intricata, hyphae compacted, hyaline to slightly orange, thin-walled, $2.5-5 \mu \mathrm{m}(\mathrm{n}=43)$ wide; subperithecial tissues of textura epidermoidea, cells hyaline, thin-walled, 7.5-20 $\times 5-14.5$ $\mu \mathrm{m}(\mathrm{n}=30)$; tissue at the base of textura intricata, hyphae hyaline, thin-walled, $1.5-4 \mu \mathrm{m}(\mathrm{n}=34)$ wide. Perithecia flask-shaped or globose, $107-210.5 \times 67.5-210 \mu \mathrm{m}(\mathrm{n}=30)$; peridium hyaline to orange, $6-11.5 \mu \mathrm{m}$ thick at flanks, 7.5-15 $\mu \mathrm{m}$ thick at the base $(\mathrm{n}=30)$. Ostioles $12.5-20 \mu \mathrm{m}$ wide at apex, 37.5-55 $\mu \mathrm{m}$ high $(\mathrm{n}=30)$. Asci cylindrical, 59-77.5 $\times 3-4.5 \mu \mathrm{m}$, with a stipe $3.5-13.5 \mu \mathrm{m}$ long $(\mathrm{n}=30)$. Ascospores hyaline, verrucose, cells dimorphic, distal cells subglobose to oblong, 2.5-3.5 $\times 2-2.5 \mu \mathrm{m}, \mathrm{L} / \mathrm{W} 1-1.5(-1.6)$, proximal cells oblong to ellipsoidal, 2-3.5 $\times 1.5-2.5 \mu \mathrm{m}$, L/W (1.1-)1.3-1.8(-2) $(\mathrm{n}=50)$.

Colony on CMD 39-53 mm in radius after $72 \mathrm{~h}$ at $25{ }^{\circ} \mathrm{C}$, mycelium covering the plate after 5 d. Colony circular, whitish, reverse side yellowish; aerial hyphae distributed homogeneously and intertwined, forming whitish $c .0 .1-0.5 \mathrm{~mm}$ diam. granules after $7 \mathrm{~d}$ near the plug. Conidiation noted after $2 \mathrm{~d}$ on aerial hyphae. Conidiophores trichoderma-like, branches at an acute or right angle to the main axis, generally re-branching 1 or 2 times. Phialides subulate or ampulliform, solitary or divergent in whorls of 2-6, 7-19 $\times 2-3.5 \mu \mathrm{m}, \mathrm{L} / \mathrm{W} 3-6.5(-7)$, base $1.5-3(-3.3) \mu \mathrm{m}(\mathrm{n}=$ 54). Conidia hyaline, globose to ellipsoid, $2-3.5(-5) \times 1.5-2.5 \mu \mathrm{m}$, L/W $1-1.6(-2.1)(\mathrm{n}=37)$. Odor coconut-like; pigment yellowish.

Colony on PDA $45-53 \mathrm{~mm}$ in radius after 72 hat $25^{\circ} \mathrm{C}$, mycelium covering the plate after 5 d. Colony circular, slightly zonate, reverse side yellowish; aerial hyphae dense, forming granules after $7 \mathrm{~d}$ in the concentric zones. Conidiation noted after $2 \mathrm{~d}$ on aerial hyphae near the plug. Odor coconut-like; pigment yellowish.

Colony on SNA $12-19 \mathrm{~mm}$ in radius after $72 \mathrm{~h}$ at $25^{\circ} \mathrm{C}$, covering the plate after $7 \mathrm{~d}$. Colony circular, thin; aerial hyphae loosely disposed. Conidiation noted after $2 \mathrm{~d}$ on aerial hyphae. No distinct odor and diffusing pigment produced.

Material examined - CHINA, Tibet Autonomous Region, Mêdog County, $29^{\circ} 19.85^{\prime} \mathrm{N}$, 95 $18.65^{\prime}$ E, alt. $800 \mathrm{~m}$, on rotten twig, 20 September 2016, Y.B. Zhang, Z.Q. Zeng, Z.H. Yu, H.D. Zheng, X.C. Wang \& K. Chen 11058 (HMAS254526holotype); ex-type culture HMAS248898; Tibet Autonomous Region, Mêdog County, 29 $19.84^{\prime} \mathrm{N}, 9^{\circ} 18.67^{\prime} \mathrm{E}$, alt. $800 \mathrm{~m}$, on rotten twig, 20 September 2016, Y.B. Zhang, Z.Q. Zeng, Z.H. Yu, H.D. Zheng, X.C. Wang \& K. Chen 11065 (HMAS275662, culture HMAS247234).

Notes - As the sister of $T$. voglmayrii, T.medogense forms yellow-brown to purple red stromata and trichoderma-like conidiophores which are similar to $T$. voglmayrii, but ostioles apapillate, and subcotical tissue of textura intricata are apparently diagnostic. In addition, the phyalides of $T$. voglmayrii are wider [(5.5-)7.2-12.2(-16.5) $\times(2.7-) 3.2-4.1(-4.7) \mu \mathrm{m}]$, its conidia are larger [(3-)3.5-6.5(-10.5)× (2.2-)2.6-3.3(-4.2) $\mu \mathrm{m}]$, and crystals producing on CMD medium(Jaklitsch et al. 2005) were not observed in T.medogense. As sequence divergences are concerned, 82-86 bp and $151 \mathrm{bp}$ differences among $1073 \mathrm{bp}$ and $1314 \mathrm{bp}$ for RPB2 and TEF1respectivelyare detectedbetween the two fungi. They cannot be conspecific.

Trichodermapalidulum Y.B. Zhang \& W.Y. Zhuang, sp. nov.

Fig. 4

Fungal Names: FN570503; Facesoffungi number: FoF 03917

Etymology-The specific epithet refers to the somewhat pale-colored colony. 

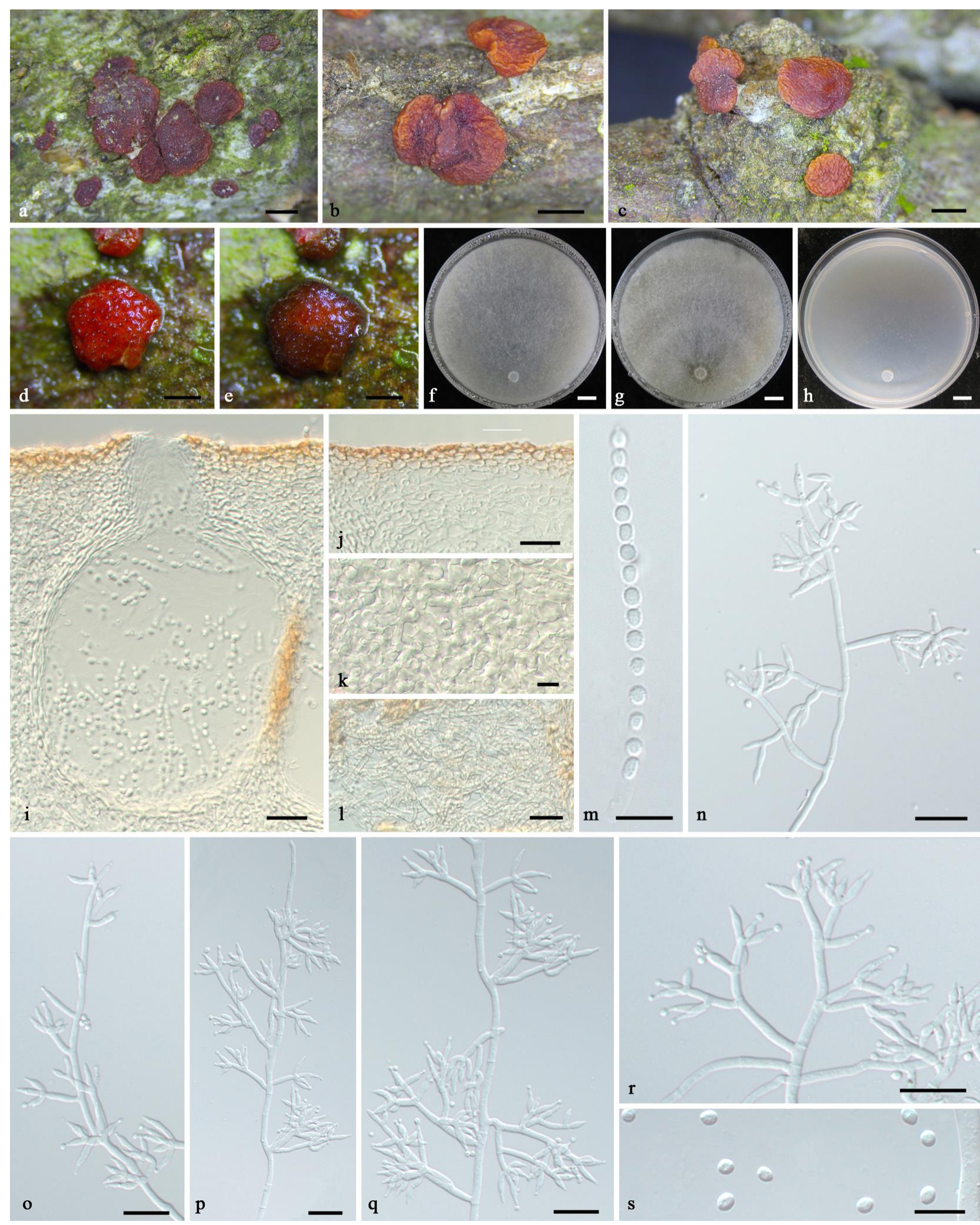

Figure 3 - Trichoderma medogense.a-c Stromata on natural substrate d Stroma after rehydration e Rehydrated stroma in $3 \% \mathrm{KOH} \mathrm{f}-\mathrm{h}$ Cultures after 7 days at $25^{\circ} \mathrm{C}(\mathrm{f} \mathrm{CMD}, \mathrm{g}$ PDA, h SNA) i Perithecium in section $\mathrm{j}$ Cortical and subcortical tissues in section $\mathrm{k}$ Subperithecial tissue in section 1 Stroma base in section m Ascusn-r Conidiophores and phialides (CMD, 2days) s Conidia (CMD, 6 days). - Photos: $\mathrm{a}, \mathrm{d}, \mathrm{e}=\mathrm{HMAS} 25452, \mathrm{~b}, \mathrm{c}, \mathrm{f}-\mathrm{s}=\mathrm{HMAS275662}$. - Scale bars: $\mathrm{a}-\mathrm{c}, \mathrm{f}-\mathrm{h}=10 \mathrm{~mm}$, $\mathrm{d}, \mathrm{e}=500 \mu \mathrm{m}, \mathrm{i}-1, \mathrm{n}-\mathrm{r}=20 \mu \mathrm{m}, \mathrm{m}, \mathrm{s}=10 \mu \mathrm{m}$. 
Stromata solitary or gregarious, pulvinate, outline irregular, broadly attached, margin free, yellowish brown, $0.5-1.5 \mathrm{~mm}$ diam., $0.2-0.5 \mathrm{~mm}$ thick $(\mathrm{n}=70)$. Surface smooth. Ostiolar dots inconspicuous or slightly dark areola. Rehydrated stromata turning reddish brown in $3 \% \mathrm{KOH}$.

In section, cortical tissue of textura angularis, 13.5-22 $\mu \mathrm{m}$ thick $(\mathrm{n}=30)$, cells slightly orange, thick-walled, 2.5-6 $\times 2.5-4 \mu \mathrm{m}(\mathrm{n}=30)$, becoming darkened in $3 \% \mathrm{KOH}$; subcortical tissue of textura intricata, hyphae hyaline, thin-walled, $1.5-4.5 \mu \mathrm{m}(\mathrm{n}=30)$ wide; subperithecial tissue of textura epidermoidea, cells hyaline, thin-walled, 8.5-27 $\times 5.5-12 \mu \mathrm{m}(\mathrm{n}=33)$; tissue at the base of textura angularis and textura intricata, hyphae hyaline, thin-walled, 2.5-6.5 $\mu \mathrm{m}(\mathrm{n}=30)$ wide, cells hyaline, thin-walled, 4.5-11 × 4-8.5 $\mu \mathrm{m}(\mathrm{n}=30)$. Perithecia flask-shaped or globose, $(153.5-) 174.5-228.5 \times(99.5-) 112.5-166 \mu \mathrm{m}(\mathrm{n}=30)$; peridium hyaline, $8.5-14 \mu \mathrm{m}$ thick at flanks, 9.5-17 $\mu \mathrm{m}$ thick at the base $(\mathrm{n}=30)$. Ostioles $16.5-29 \mu \mathrm{m}$ wide at apex, 41.5-66.5 $\mu \mathrm{m}$ high $(\mathrm{n}=30)$. Asci cylindrical, 66-82.5 × 3.5-6 $\mu \mathrm{m}(\mathrm{n}=31)$, sessile. Ascospores hyaline, verrucose, cells dimorphic, distal cells globose to subglobose, 2.5-4.5 × 3-4.5 $\mu \mathrm{m}$, L/W 1-1.3, proximal cells subglobose to ellipsoidal, $3-5 \times 2.5-3.5 \mu \mathrm{m}, \mathrm{L} / \mathrm{W} 1-1.5(\mathrm{n}=37)$.

Colony on CMD 36-45 mm in radius after $72 \mathrm{~h}$ at $25^{\circ} \mathrm{C}$, mycelium covering the plate after 5 d. Colony circular, greenish; aerial hyphae abundant in the distal part of the colony. Conidiation noted after $3 \mathrm{~d}$ on aerial hyphae. Pigment yellowish, no odor formed.

Colony on PDA $37-40 \mathrm{~mm}$ in radius after 72 hat $25^{\circ} \mathrm{C}$, mycelium covering the plate after 5 d. Colony nearly circular, slightly zonate, greenish; aerial hyphae short, erect, and downy. Conidiation noted after $3 \mathrm{~d}$ on aerial hyphae. Pigment yellowish, no odor formed.

Colony on SNA $8-15 \mathrm{~mm}$ in radius after $72 \mathrm{~h}$ at $25^{\circ} \mathrm{C}$, covering the plate after $28 \mathrm{~d}$. Colony nearly circular, thin; aerial hyphae loosely distributed. Conidiation noted after $3 \mathrm{~d}$ on aerial hyphae around the plug. Conidiophores verticillium- to trichoderma-like, branches arising from the main axis at an acute or right angle, mostly re-branching once. Phialides subulate or ampulliform, solitary or divergent in whorls of 2-5, 6.5-14 × 2-3 $\mu \mathrm{m}$, L/W 2.9-7.2, base 1-2.5 $\mu \mathrm{m}(\mathrm{n}=45)$. Conidia green, subglobose to ellipsoid, 3.5-5 × 2.5-3.5 $\mu \mathrm{m}$, L/W 1.2-1.5(-1.7) $(\mathrm{n}=36)$. Pigment yellowish, no odor formed.

Material examined - CHINA, Yunnan, Maguan County, 22 $56.58^{\prime} \mathrm{N}, 104^{\circ} 32.60^{\prime} \mathrm{E}$, alt. 2000 m, on rotten twig, 11 August 2016, X.H. Wang, S.H. Li, H.D. Zheng \& S.C. Li YN16-80 (HMAS275665 holotype); ex-type culture HMAS247237; Yunnan, Maguan County, $23^{\circ} 6.21^{\prime} \mathrm{N}$, $104^{\circ} 19.75^{\prime}$ E, alt. $1450 \mathrm{~m}$, on rotten twig, 14 August 2016, X.H. Wang, S.H. Li, H.D. Zheng \& S.C. Li YN16-161 (HMAS254527, culture HMAS247238).

Notes - The new species shares common ancestor with $T$. petersenii, $T$. istrianum and $T$. caribbaeum (Fig.1). Trichoderma petersenii and T. istrianum are easily distinguished from $T$. palidulum by velvety and semi-effused stomata, and larger perithecia [(166-)190-375(-485)× (90)125-265(-370) $\mu \mathrm{m}$ in $T$. petersenii, (120-)145-205(-225) $\times(95-) 105-180(-220) \mu \mathrm{m}$ in $T$. istrianum] (Samuels et al. 2006, Jaklitsch \& Voglmayr 2015).In T. caribbaeum, the stromata do not react to $\mathrm{KOH}$, cortex is thicker $(20-35 \mu \mathrm{m})$, subcortical tissue is of textura angularis instead of textura intricata, and the growth is faster than that of the new species (on PDA: 53-56 mm after 72 h, on SNA: 41-42 mm after $72 \mathrm{~h}$ ) (Samuels et al. 2006). There were also sequence divergences with 59-60 bp differences for TEF1 (95\%) and 26-29 bp divergences for RPB2 (98\%).

Trichodermavirgineum Y.B. Zhang \& W.Y. Zhuang, sp. nov.

Fig. 5

Fungal Names: FN570504; Facesoffungi number: FoF 03918

Etymology - The specific epithet refers to the white colony of the fungus.

Stromata solitary, gregarious, or aggregated in small numbers, pulvinate or lenticular,outline circular, lobed, or irregular, centrally attached, pale bright yellow when fresh, raw sienna when mature, $1-3.5 \mathrm{~mm}$ diam., $0.5-1 \mathrm{~mm}$ thick $(\mathrm{n}=40)$. Surface nearly smooth. Ostiolar dots dark brown, distinct, densely distributed. Rehydrated stromata turning antique brown in $3 \% \mathrm{KOH}$.

In section, cortical tissue of textura angularis, $12-18 \mu \mathrm{m}$ thick $(\mathrm{n}=30)$, cells yellowish brown, thick-walled, 2.5-9.5 $\times 2-6 \mu \mathrm{m}(\mathrm{n}=30)$, becoming rufous in $3 \% \mathrm{KOH}$; subcortical tissue of textura intricata, hyphae hyaline, thin-walled, 2-3.5 $\mu \mathrm{m}(\mathrm{n}=39)$ wide; subperithecial tissue of 


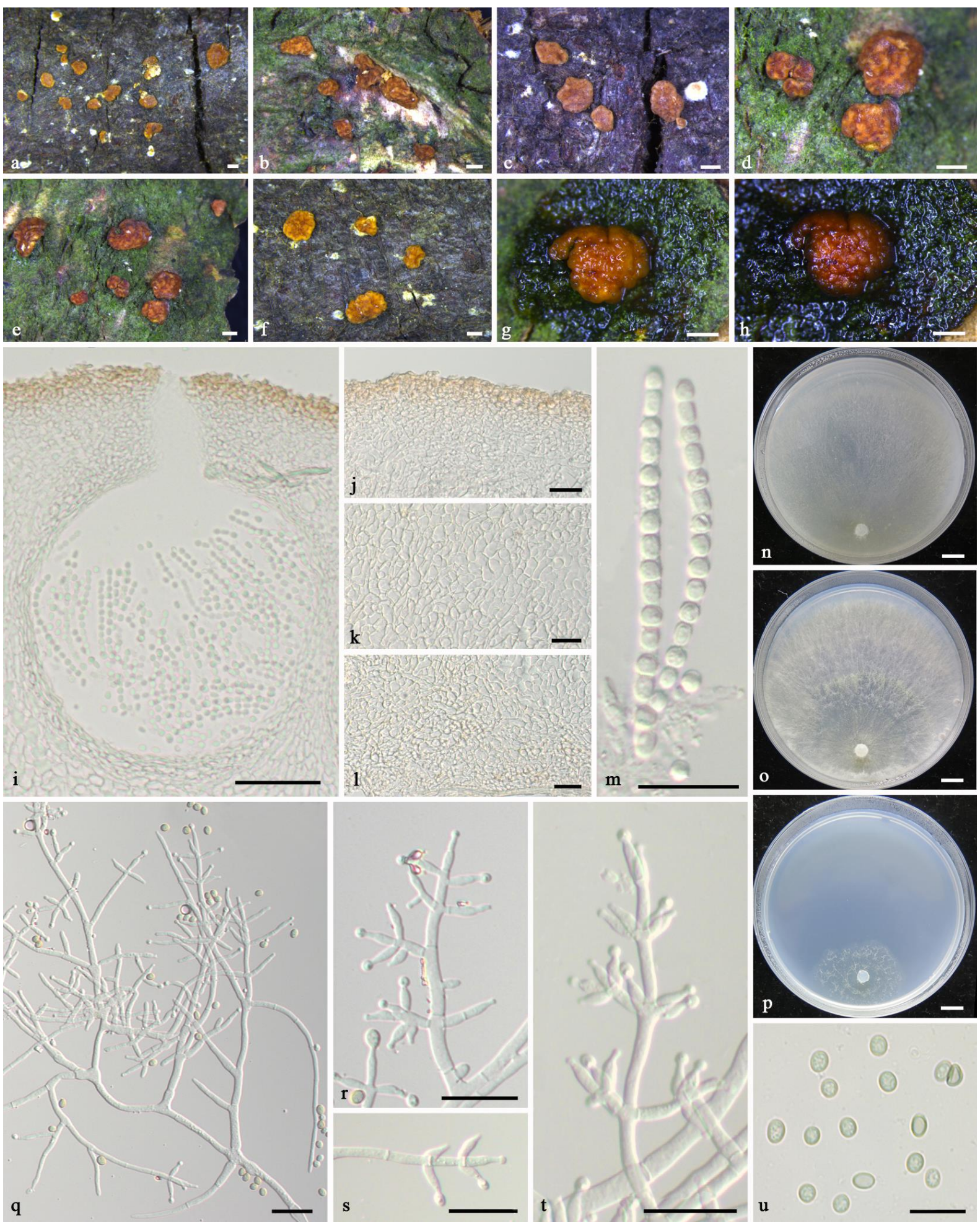

Figure 4- Trichoderma palidulum. a-f Dry stromata on natural substrate g Mature stroma after rehydration $\mathrm{h}$ Rehydrated mature stroma in $3 \% \mathrm{KOH}$ i Perithecium in section $\mathrm{j}$ Cortical and subcortical tissues in section $\mathrm{k}$ Subperithecial tissue in section 1 Stroma base in section $\mathrm{m}$ Asci $\mathrm{n}-\mathrm{p}$ Cultures after 5 days at $25^{\circ} \mathrm{C}$ (n CMD, o PDA, p SNA) q-t Conidiophores and phialides (CMD, 3days) u Conidia (SNA, 13 days). -Photos: a, $\mathrm{c}, \mathrm{i}-\mathrm{l}, \mathrm{s}-\mathrm{t}=\operatorname{HMAS} 254527, \mathrm{~b}, \mathrm{~d}-\mathrm{h}, \mathrm{m}-\mathrm{r}, \mathrm{u}=$ HMAS275665. - Scale bars: $\mathrm{a}-\mathrm{h}=500 \mu \mathrm{m}, \mathrm{i}=50 \mu \mathrm{m}, \mathrm{j}-\mathrm{m}, \mathrm{q}-\mathrm{t}=20 \mu \mathrm{m}, \mathrm{n}-\mathrm{p}=10 \mathrm{~mm}, \mathrm{u}=10 \mu \mathrm{m}$.

textura epidermoidea, cells hyaline, thin-walled, 4.5-15 $\times 3-7 \mu \mathrm{m}(\mathrm{n}=30)$; tissue at the base of textura epidermoidea mixed with textura angularis, cells hyaline to slightly yellow, thin-walled, 4$10.5 \times 3.5-7 \mu \mathrm{m}(\mathrm{n}=31)$. Perithecia flask-shaped or globose, $165-200 \times 93-142 \mu \mathrm{m}(\mathrm{n}=30)$; 
peridium pale yellow, slightly darkened in $3 \% \mathrm{KOH}, 6-11.5 \mu \mathrm{m}$ thick at flanks, $8.5-12.5 \mu \mathrm{m}$ thick at the base $(\mathrm{n}=30)$. Ostioles $12.5-20 \mu \mathrm{m}$ wide at apex, 30.5-45 $\mu \mathrm{m}$ high $(\mathrm{n}=30)$. Asci cylindrical, sessile, 41.5-66 $\times 2-4 \mu \mathrm{m}(\mathrm{n}=30)$. Ascospores hyaline, spinulose, cells monomorphic, distal cells globose to subglobose, $2-3.5 \times 2-3 \mu \mathrm{m}, \mathrm{L} / \mathrm{W} 1-1.4(\mathrm{n}=30)$, proximal cells globose to subglobose, $2-3.5 \times 1.5-3 \mu \mathrm{m}, \mathrm{L} / \mathrm{W} 1-1.5(\mathrm{n}=30)$.

Colony on CMD $48-51 \mathrm{~mm}$ in radius after $72 \mathrm{~h}$ at $25{ }^{\circ} \mathrm{C}$, mycelium covering the plate after 5 d. Colony circular, thin, with well-defined margin; aerial hyphae rarely. No conidiation observed within $15 \mathrm{~d}$. Chlamydospores noted after $25 \mathrm{~d}$. Odor slightly fruity; no pigment observed.

Colony on PDA 24-30 mm in radius after 72 hat $25^{\circ} \mathrm{C}$, mycelium covering the plate after 25 d. Colony nearly circular, with wavy margin; aerial hyphae intertwined, forming a dense white mat. No conidiation observed within $15 \mathrm{~d}$. Chlamydospores noted after $25 \mathrm{~d}$, abundant, terminal or intercalary, globose or ellipsoidal, $6.5-23.5 \times 7.0-22.5 \mu \mathrm{m}(\mathrm{n}=30)$. Odor slightly fruity; no pigment observed.

Colony on SNA 33-35 mm in radius after $72 \mathrm{~h}$ at $25^{\circ} \mathrm{C}$, mycelium covering the plate after 10 d. Colony nearly circular, thin, radial; aerial hyphae rarely distributed, becoming cottony near the plate margin. Conidiation noted after $15 \mathrm{~d}$ on aerial hyphae. Conidiophores acremonium-like, branches arise from the main axis. Phialides narrowly subulate, mostly solitary, $12-22.5(-26) \times 2-$ $3.5 \mu \mathrm{m}, \mathrm{L} / \mathrm{W} 5-9$, base 1.5-3.2 $\mu \mathrm{m}(\mathrm{n}=49)$. Conidia hyaline, oblong or ellipsoid, rarely cylindrical, 3.5-6.5(-8) $\times 2-3.5 \mu \mathrm{m}, \mathrm{L} / \mathrm{W} 1-2.6(-2.8)(\mathrm{n}=30)$. No chlamydospores observed within $25 \mathrm{~d}$. No distinct odor and diffusing pigment formed.

Material examined - CHINA, Yunnan, Maguan County, $22^{\circ} 49.55^{\prime} \mathrm{N}, 104^{\circ} 24.55^{\prime} \mathrm{E}$, alt. 1565 m, on rotten twig, 13 August 2016, X.H. Wang, S.H. Li, H.D. Zheng \& S.C. Li YN16-110 (HMAS275664 holotype); ex-type culture HMAS247236.

Notes - In Fig.1, T. virgineum, T. henanense and T. odoratum formed a clade which is not closely related to any of the existing clades. These three species are similar in yellowish stromata, monomorphic ascospores, white colonies, simply branched conidiophores and hyaline conidia (Qin \& Zhuang 2016c). However, T. odoratum differs in projecting, higher and wider ostioles [projecting by (8-) 16-21 $\mu \mathrm{m}, 53-66(-74) \mu \mathrm{m}$ high, $(29-) 32-40(-42) \mu \mathrm{m}$ wide], longer and wider asci $[(62-) 68-82(-89) \times 4.2-5(-5.5) \mu \mathrm{m}]$, smaller growth rate and the mushroom-like odor in cultures. Compared with the sequences of RPB2 and TEF1, similarities were $94 \%$ and $93 \%$ with 68 bp and 84 bp differences among 1073 and 1261 bp respectively. Trichoderma henanense has larger cells in cortical, subperithecial and basal tissues [respectively $(4.5-) 6-8.5(-10.5) \times(4-) 4.5-8(-10)$ $\mu \mathrm{m}, 8-19(-24) \times 7.5-14(-19) \mu \mathrm{m}$, and $(5-) 6-13(-16) \times(4-) 5-10(-12) \mu \mathrm{m}]$ than the new species. In its anamorphic state, $T$. henanensegrows slower than the new species on CMD and PDA media (19-31 mm on CMD and 19-21 mm on PDA after $72 \mathrm{~h}$ at $25^{\circ} \mathrm{C}$ ), produces denser aerial hyphae on CMD and distinctly abundant chlamydospores on SNA. Sequence comparisons indicate there are $61 \mathrm{bp}$ divergences among $1073 \mathrm{bp}$ for RPB2 and 45 bp among 1064 bp for TEF1.

\section{Discussion}

Phylogenetic analyses of the 60Trichoderma species were carried out based on analyses of the combined sequences ofRPB2 and TEF1to allocate the phylogenetic positions of the four new species. The analyses included representatives of almost all the named clades of the genus and some scattered terminal branches. The resulted tree (Fig.1) is basically congruent with the previous studies(Jaklitsch 2009; Jaklitsch \&Voglmayr 2015; Qin \& Zhuang 2016c; Zhu \& Zhuang 2015a,b), in which 15 clades were recognized with five possessing green ascospores, and ten giving rise to hyaline ascospores. The four newly described species are among the hyaline-ascospored groups. One of them belongs to the Viride clade, two are as separate terminal branches, and one clusterswith two knownspecies forming a new clade.

Trichoderma fructicola, featured by cortical tissues of textura epidermoidea and occurring ona rotten fruit, isseemingly associated with the Hypocreanum and Psychophilum clades, which 

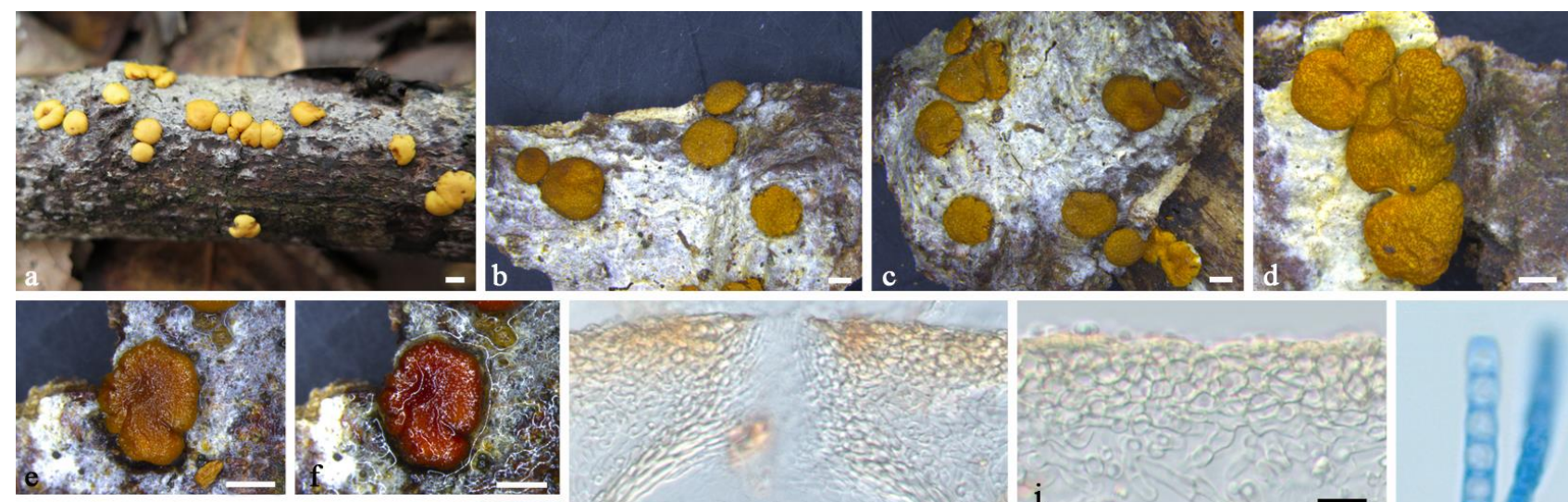

(x)
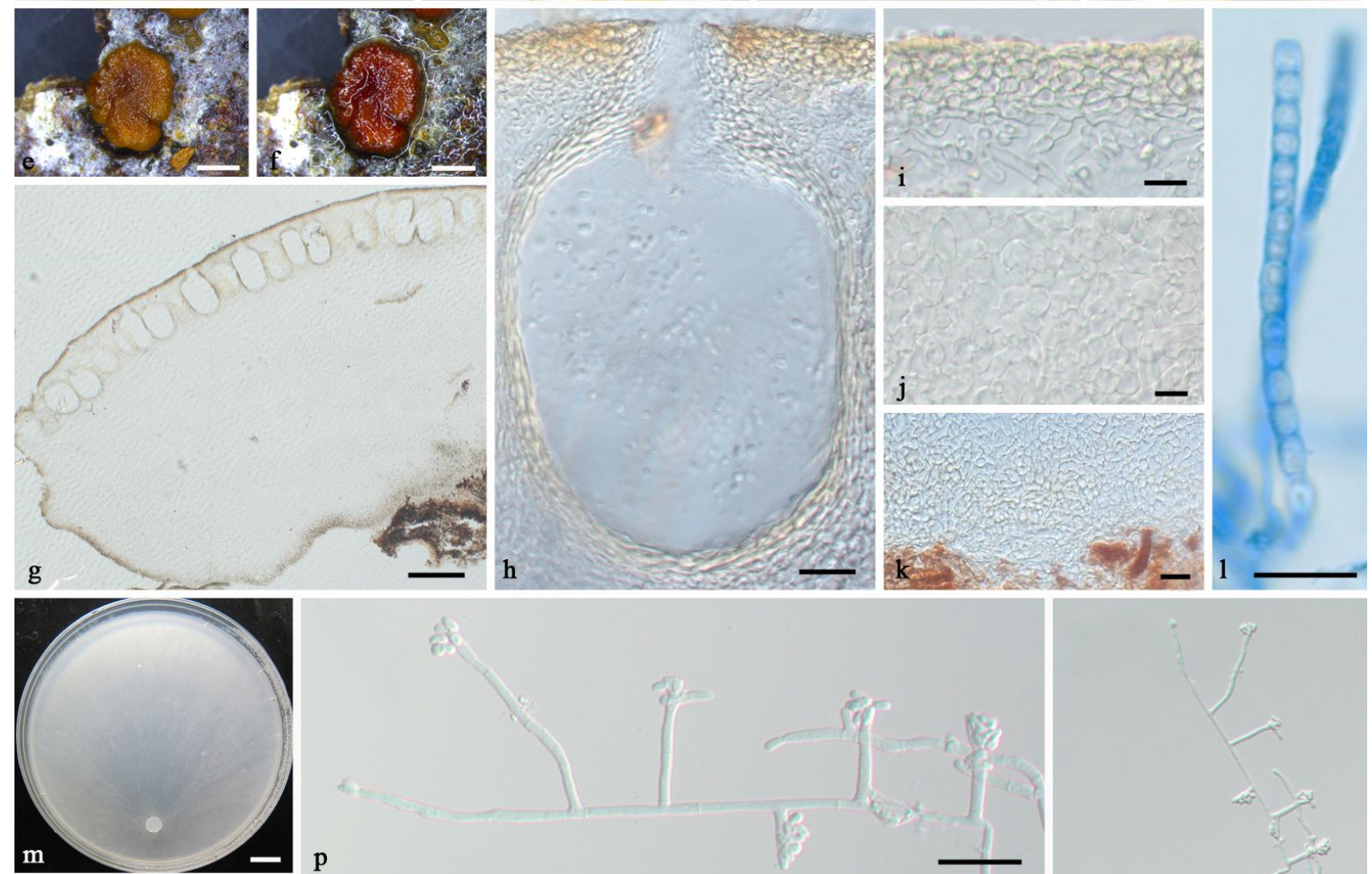

h
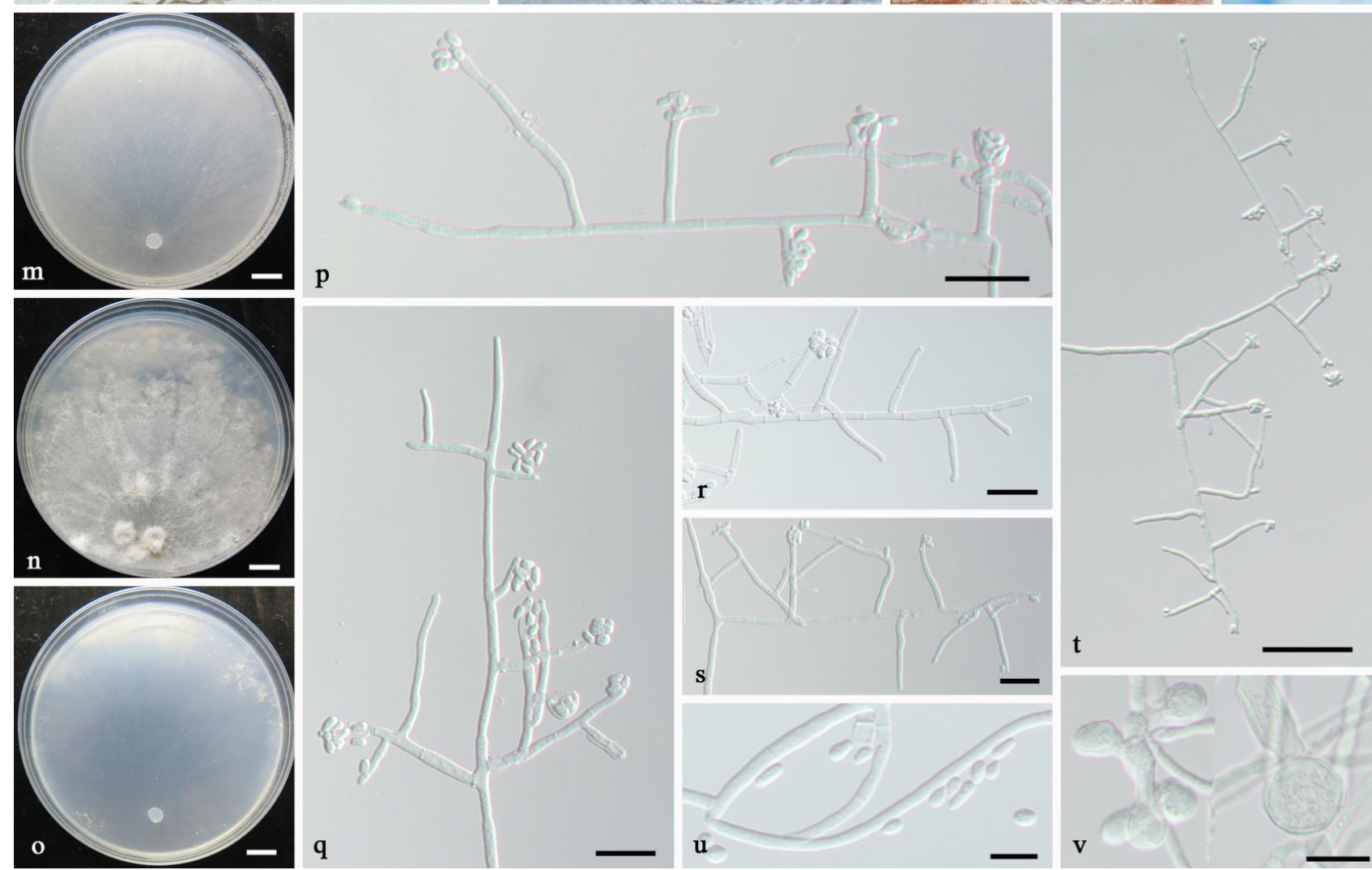

Figure 5- Trichoderma virgineum(HMAS275664). a Fresh stromata on natural substrate b-d Dry stromata on natural substrate e Mature stroma after rehydration f Rehydrated mature stroma in 3\% $\mathrm{KOH} g$ Longitudinal section of stroma h Perithecium in section i Cortical and subcortical tissues in section $\mathrm{j}$ Subperithecial tissue in section $\mathrm{k}$ Stroma base in section 1 Ascus $\mathrm{m}-\mathrm{o}$ Cultures after 30 days at $25^{\circ} \mathrm{C}$ (m CMD, n PDA, o SNA) p-t Conidiophores and phialides (SNA, 25days) u Conidia (SNA, 25 days) v Chlamydospores (PDA, 25 days). - Scale bars: $\mathrm{a}=2 \mathrm{~mm}, \mathrm{~b}-\mathrm{f}, \mathrm{m}-\mathrm{O}=1 \mathrm{~mm}, \mathrm{~g}=$ $200 \mu \mathrm{m}, \mathrm{h}, \mathrm{k}, \mathrm{p}-\mathrm{s}, \mathrm{u}, \mathrm{v}=20 \mu \mathrm{m}, \mathrm{i}, \mathrm{j}=10 \mu \mathrm{m}, \mathrm{t}=50 \mu \mathrm{m}$. 
Nevertheless lacks of sufficient support (Fig.1). Trichoderma medogense is closely associated with T. voglmayrii $(\mathrm{MPBP} / \mathrm{BIPP}=100 \% / 100 \%)$. They formed a small but highly supported group $(\mathrm{MPBP} / \mathrm{BIPP}=100 \% / 100 \%)$. They both occur at high elevation sites, and have similar stroma color and conidiophore branching pattern. This new fungus is clearly distinguishable in structure of subcortical tissues, shape of phialides, and especially size of conidia. Trichoderma palidulum shares some common features with others in the Viride clade, such as brown to rufous stromata with inconspicuous ostiolar dots, hyaline ascospores, and green conidia. In the phylogenetic analyses, it is associated with $T$. petersenii, $T$. istrianum and $T$. caribbaeum, but differs significantly in many other aspects as already mentioned in the notes.

The regional monographic treatments of Trichoderma species having hyaline ascospores were carried out by Jaklitsch (2011) and Jaklitsch \& Voglmayr (2015). The hyaline-ascospored species of the genus were in ten clades, including the recently added Asterineum clade specialized by ostiolar dots surrounded by stellate cracks. Among the known species, T. virgineum shares phenotypic similarity with $T$. odoratum and $T$. henanense, and is closely related to them with high statistic supports(MPBP/BIPP $=100 \% / 100 \%)$. These three species are common inyellowish stromata, white colonies on three standard media, monomorphic ascospores, acremonium- or verticillium-like conidiophores, and hyaline conidia. The Virgineum clade is here proposed. Among the existingclades, the Hypocreanum clade forms also simple conidiophore branch patterns and hyaline conidia, however, speciesof that clade have extensively effused stromata and mostlypossess vertically parallel and warted hyphae above stroma surface(Overton et al. 2006). It is remotely related to the Virgineum clade (Fig.1).

Many new species of Trichoderma have been published successively based on the materials collected from this country in the past four years (Zhu \& Zhuang 2014, 2015a,b, Qin \& Zhuang 2016a,b,c, 2017, Chen \& Zhuang 2017a,b,c). We believe that more taxa will be discovered in the unexplored regions, which will definitely renew our understanding of species diversity, resources, taxonomy and phylogeny of the genus, and which will certainly broaden our knowledge of application of useful fungal resources.

\section{Acknowledgements}

The authors are very thankful to all collectors of the specimens used in the study, and Ms. Xia Song for the technical assistance. This project was supported by the National Natural Science Foundation of China (no. 31570018) and Ministry of Science and Technology of China for Fundamental Research (no. 2013FY110400) to WYZ.

\section{References}

Adnan LA, Sathishkumar P, Yusoff AR, Hadibarata T et al. 2017 - Rapid bioremediation of Alizarin Red Sand Quinizarine Green SS dyes using Trichoderma lixiiF21 mediated by biosorption and enzymatic processes. Bioprocess and Biosystems Engineering40: 85-97.

Bischof RH, Ramoni J, Seiboth B. 2016 - Cellulases and beyond: the first 70 years of the enzyme producer Trichoderma reesei. Microbial Cell Factories 15: 1-13.

Bissett J, Gams W, Jaklitsch W, Samuels GJ. 2015 - Accepted Trichoderma names in the year 2015. IMA Fungus 6(2): 263-295.

Chaverri P, Samuels GJ. 2003 - Hypocrea/Trichoderma (Ascomycota, Hypocreales, Hypocreaceae) species with green ascospores. Studies in Mycology 48: 1-116.

Chen K, Zhuang WY. 2017a - Three new soil-inhabiting species of Trichoderma in Stromaticum clade with test of their antagonism to pathogens. Current Microbiology 74: 1049-1060.

Chen K, Zhuang WY. 2017b - Seven soil-inhabiting new species of the genus Trichoderma in the Viride clade. Phytotaxa 312: 28-46.

Chen K, Zhuang WY. 2017c - Discovery from a large-scaled survey of Trichoderma in soil of China. Scientific Reports 7: 9090. 
Cunningham CW. 1997 - Can three incongruence tests predict when data should be combined? Molecular Biology and Evolution14: 722-740.

Druzhinina I, Kubicek CP. 2005 - Species concepts and biodiversity in Trichoderma and Hypocrea: from aggregate species to species clusters? Journal of Zhejiang University-Science 6B: $100-112$.

Harman GE. 2006 - Overview of mechanisms and uses of Trichoderma spp. Phytopathology 96: 190-194.

Jaklitsch WM, Samuels GJ, Dodd SL, Lu BS et al. 2006 - Hypocrea rufa/Trichoderma viride: a reassessment, and description of five closely related species with and without warted conidia. Studies in Mycology 56: 135-177.

Jaklitsch WM. 2009 - European species of Hypocrea I. The green-spored species. Studies in Mycology 63: 1-91.

Jaklitsch WM. 2011 - European species of Hypocrea II. species with hyaline ascospores. Fungal Diversity 48: 1-250.

Jaklitsch WM, Komon M, Kubicek CP, Druzhinina IS. 2005 - Hypocrea voglmayrii sp. nov. from the Austrian Alps represents a new phylogenetic clade in Hypocrea/Trichoderma. Mycologia 6: $1365-1378$.

Jaklitsch WM, Voglmayr H. 2015 - Biodiversity of Trichoderma (Hypocreaceae) in Southern Europe and Macaronesia. Studies in Mycology80: 1-87.

Kredics L, Hatvani L, Naeimi S, Körmöczi P et al. 2010 - Biodiversity of the genus Hypocrea/Trichoderma in different habitats. In Biotechnology and Biology of Trichoderma; Gupta VK, Schmoll M, Herrera-Estrella A, Upadhyay RS, Druzhinina I, Tuohy M, Eds. Elsevier: Amsterdam, The Netherlands pp. 3-24.

Nirenberg H. 1976 - Untersuchungen über die morphologische und biologische Differenzierung in der Fusarium-Sektion Liseola. Mitteilungen aus der Biologischen Bundesanstalt für Land-und Forstwirtschaft, Berlin-Dahlem 169: 1-117.

Nylander JAA. 2004 - MrModeltest v2. Program distributed by the author. Evolutionary Biology Centre, Uppsala University, Uppsala.

Overton BE, Stewart EL, Geiser DM, Jaklitsch WM. 2006 - Systematics of Hypocrea citrine and related taxa. Studies in Mycology 56: 1-38.

Qin WT, Zhuang WY. 2016a - Two new hyaline-ascospored species of Trichoderma and their phylogenetic positions. Mycologia 108: 205-214.

Qin WT, Zhuang WY. 2016b - Seven wood-inhabiting new species of the genus Trichoderma (Fungi, Ascomycota) in Viride clade. Scientific Reports 6: 27074.

Qin WT, Zhuang WY. 2016c - Four new species of Trichoderma with hyaline ascospores from central China. Mycological Progress 15: 811-825.

Qin WT, Zhuang WY. 2017 - Seven new species of Trichoderma (Hypocreales) in the Harzianum and Strictipile clades. Phytotaxa 305: 121-139.

Rambaut A. 2016 - FigTree. Tree figure drawing tool, v.1.4.3. Available from: http://tree.bio.ed.ac.uk/

Ronquist F, Huelsenbeck JP. 2003 - MrBayes 3: Bayesian phylogenetic inference under mixed models. Bioinformatics 19: 1572-1574.

Samuels GJ, Dodd S, Lu BS, Petrini O et al. 2006 - The Trichoderma koningii aggregate species. Studies in Mycology 56: 67-133.

Saravanakumar K, Kathiresan K. 2014 - Bioconversion of lignocellulosic waste to bioethanol by Trichoderma and yeast fermentation. 3 Biotech 4: 493-499.

Sun JZ, Pei YF, Li EW, Li W et al. 2016 - A new species of Trichoderma hypoxylon harbours abundant secondary metabolites. Scientific Reports 6:37369.

Swofford DL. 2002 - PAUP*: Phylogenetic Analysis using Parsimony (*and other methods). version 4b10. Sinauer Associates, Sunderland, Massachusetts, USA. 
Thompson JD, Gibson TJ, Plewniak F, Jeanmougin F et al. 1997 - The CLUSTAL X windows interface: flexible strategies for multiple sequence alignment aided by quality analysis tools. Nucleic Acids Research 25: 4876-4882.

Wang L, Zhuang WY. 2004 - Designing primer sets for amplification of partial calmodulin genes from penicillia. Mycosystema 23: 466-473.

Zhu ZX, Zhuang WY. 2014 - Two new species of Trichoderma (Hypocreaceae) from China. Mycosystema 33: 1168-1174.

Zhu ZX, Zhuang WY. 2015a - Three new species of Trichoderma with hyaline ascospores from China. Mycologia 107: 328-345.

Zhu ZX, Zhuang WY. 2015b - Trichoderma (Hypocrea) species with green ascospores from China. Persoonia 34: 113-129. 